\title{
琵琶湖疏水におけるラン藻類と その含有毒素ミクロシスチンの挙動
}

\author{
山下尚之 ${ }^{1} \cdot$ 松井三郎 $^{2} \cdot$ 清水芳久 $^{3} \cdot$ 松田知成 ${ }^{4}$ \\ ${ }^{1}$ 京都大学大学院博士課程 工学研究科附属環境質制御研究セン夕ー（テ520-0811 滋賀県大津市由美浜 1-2） \\ ${ }^{2} \mathrm{Ph} . \mathrm{D}$ 京都大学教授 工学研究科環境工学専攻 (T606-8501 京都市左京区吉田本町) \\ ${ }^{3} \mathrm{Ph} . \mathrm{D}$ 京都大学助教授 工学研究科附属環境質制御研究センター（テ520-0811 滋賀県大津市由美浜 1-2） \\ ${ }^{4}$ 工博 京都大学助手 工学研究科附属環境質制御研究センター（予520-0811 滋賀県大津市由美浜 1-2)
}

\begin{abstract}
琵琶湖疏水は, 琵琶湖から京都市にかけて人工的に作られた水路で, その水は京都市の重要な水道水源として利用 されている.一方, 近年琵琶湖においても夏期にアオコの発生か観察されており, 琵琶湖湖水からは, アオコに含有 される毒素ミクロシスチンの検出か報告されている. そこで, 本研究ではアオコの発生時期に琵琶湖疏水において調 査を行い, 琵琶湖疏水におけるラン藻類とその含有毒素ミクロシスチンの挙動について検討を行った. その結果, 琵 琶湖疏水の水からミクロシスチンが検出され，その濃度は $300 \mathrm{pg} / \mathrm{ml}$ から $680 \mathrm{pg} / \mathrm{ml}$ の間で変化した. また，ミクロシ スチン濃度は, クロロフィルa, フィコシアニン濃度との間に相関関係が見られた. 琵琶湖疏水の水からミクロシス チンが検出されたことから, アオコ発生時期にはミクロシスチンの挙動に十分注意する必要があると考えられた.
\end{abstract}

Key Words : Lake Biwa Canal, cyanobacterial toxin, microcystin, water bloom, Anabaena, Micro cystis

\section{1. はじめに}

近年，富栄養化した湖沼において夏期にラン藻類の異 常増殖が起こり,アオコを発生させて問題となっている. このアオコは, 湖沼景観の悪化や腐敗による悪臭の発生 および浄水処理におけるろ過障害等の問題を引き起こす が, 近年アオコの原因となっているラン藻類には, 有毒 物質を含有するものがいるということが明らかにされて きている ${ }^{1)}$. 世界各国で，このアオコを含んだ水を飲ん だため家畜や野性動物が死亡したり，また人体にも影響 が現われた等の報告がなされている ${ }^{1)-3)}$.ラン藻類の生産 する毒素は数種類あり, 近年の研究によりその構造や毒 性が明らかにされてきているが, それらの毒素のうち日 本において主に問題となると考えられるものは，ミクロ シスチンと呼ばれる毒素である.このミクロシスチンは, いくつかのアミノ酸からなる環状のペプチドであるが, 肝臓に対して特異的に毒性作用を示すことが知られてい る ${ }^{4}$. また Fujiki ら 5ூのは、ミロシスチンに発ガンのブ ロモータ一作用があることを報告しており，慢性的な毒 性影響も眯念される。

琵琶湖疏水は, 琵琶湖南湖から京都市にかけて人工的 に作られた水路である. その目的は, 琵琶湖の水を京都 に引き，その水力で工業をおこすとともに，疏水を通じ
て物資の流通を盛んにするというもので, 明治 23 年に建 設された. 京都市における水道施設の整備に伴って, 琵 琶湖疏水の水は京都市の重要な水道水源として利用され るようになり, 現在では京都市の水道水の大半は, 琵琶 湖疏水からの水に頼っている. 一方, 近年琵琶湖におい ても南湖を中心として夏期にアオコの発生が観察される ようになり, 琵琶湖の湖水からは, アオコに含有される 毒素ミクロシスチンの検出が報告されている7,8).そのた め, ラン藻類により生成されたミクロシスチンが琵琶湖 疏水の水に混入し, 京都市の水道原水に流入することが 㲘念される.

琵琶湖疏水からの水は, 京都市の重要な水道水源とし て利用されており，この水にラン藻毒であるミクロシス チンが混入することは, 水道水の安全性の点から問題と なるが, 琵琶湖疏水におけるミクロシスチンの挙動に関 しては, 未だ報告がなされていない. 本研究では琵琶湖 南湖でアオコの発生が観察された1998年9月初旬に琵琶 湖疏水においてサンプリングを行い, 琵琶湖疏水におけ るラン藻類とその含有毒素ミクロシスチンの挙動につい て検討を行った. 


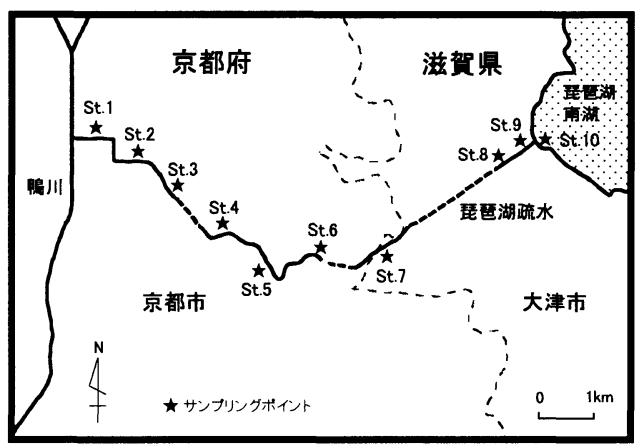

St.1 : 夷川, St.2 : 岡崎, St3 : 蹴上, St.4 : 日ノ岡, St.5 : 御陵, St.6 : 安朱, St.7 : 四ノ宮, St.8 : 大津制水門, St.9 : 疏水取水口, St.10 : 大津港

図-1 調查地点

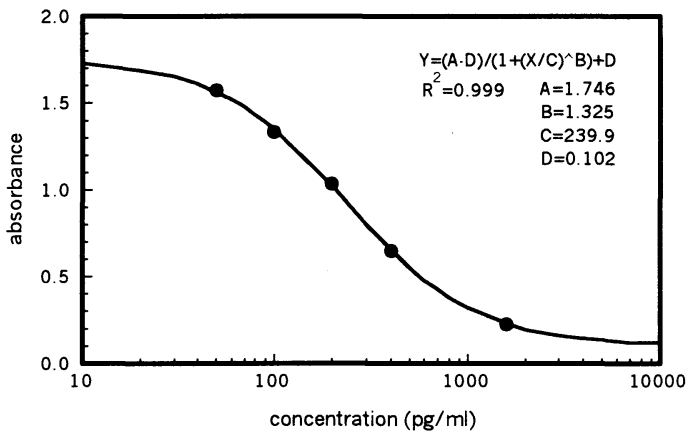

図-2 ELISA分析におけるミクロシスチンの検量線

\section{2. 調査地点および分析方法}

\section{（1）調查地点}

近年, 琵琶湖においては，南湖を中心として毎年アオ コの発生か観察されている. 1998 年については, 9月の 初旬に琵琶湖南湖においてアオコの発生が見られた. そ こで, 1998 年 9 月 5 日に, 京都市内から滋賀県大津市に ある琵琶湖疏水取水口部にかけて計 10 ケ所でサンプリ ングを行った. 調査地点を図-1 に示す. サンプリングで は，それぞれの地点においてバケツを用い表面水を採取 するとともに, 水質測定器 U-10 (HORIBA) を用いて水 温， $\mathrm{pH}$, 溶存酸素等についても測定を行った.

\section{(2) 分析方法}

採取したサンプルは, WhatmanGF/F フィルターでろ過 を行い, 湖水およびそのろ液それそれについて-20Cで凍 結保存した. また，ろ過を行ったフィルターについても
凍結保存を行い, クロロフィルaおよびフィコシアニン 等の分析に供した. プランクトンカウントのサンプルに ついては，湖水に中性ホルマリンを $5 \%$ の濃度になるよ う添加して固定した後に，サンプルを濃縮し顕微鏡下で プランクトンの計数を行った.

水中のミクロシスチンについては, 主として ELISA 法 を用いて分析を行った. 近年，ミクロシスチンに対する モノクローナル抗体が作成され，この抗体を用いた ELISA 法が開発されている9.ミクロシスチンの分析は, 凍結保存しているサンプルを融解した後に，この抗ミク ロシスチンモノクローナル抗体を用いた常盤化学工業

(株) 社製のミクロシスチン ELISA キットを用いて行つ た.ミクロシスチンの ELISA 分析における検量線を図-2 に示す.このモノクローナル抗体は, ミクロシスチン LR を抗原として作製されたものであるが, 他のタイプのミ クロシスチンとも反応性を示し, ミクロシスチン LR, YR，RRに対する交差反応性はそれぞれ 100\%，44\%， 106\%である9.

高速液体クロマトグラフィー（HPLC）を用いたミク ロシスチンの分析については, Park ら ${ }^{19}$ の方法に準拠し て行った. ろ過を行ったフィルターについて 5\%酰酸水 を用いて抽出を行い，その抽出液を ODS カートリッジ に通し，ミクロシスチンをカートリッジに吸着させた. カートリッジに吸着したミクロシスチンを 90\%メタノ 一ルにより溶出させた後に溶出液の濃縮を行い, HPLC

（Waters Co.）でミクロシスチンを分析した. カラムは， Symmetry C18 カラム $(4.6 \times 150 \mathrm{~mm})$ を用い，移動相は メタノール : 50mM リン酸バッファー $(60: 40)$ を用い た.

クロロフィルaの分析は，ろ過を行ったフィルターに ついて Lorenzen の方法 ${ }^{11)}$ に準じ行った. フィコシアニン の分析は, ろ過を行ったフィルターから $10 \mathrm{mM}$ リン酸バ ッファー $(\mathrm{pH}=7) 5 \mathrm{ml}$ を用いて $4^{\circ} \mathrm{C} て ゙ 一$ 晚抽出した後に， 蛍光光度計 $(E x .605 \mathrm{~nm}, \mathrm{Em} .640 \mathrm{~nm})$ により測定を行し た.

\section{3. 結果と考察}

\section{（1）水温 $\cdot \mathrm{pH} \cdot$ 溶存酸素等の変化}

図-3に琵琶湖疏水における水温, $\mathrm{pH}$, 溶存酸素濃度の 変化を示す. 水温については, $27.2 \sim 28.9^{\circ} \mathrm{C}$ の間で, $\mathrm{pH}$ は 7.5 9.1 の間で值は変化した. $\mathrm{pH}$ の值は, 琵琶湖疏水 取水口部の St.10 から St.8では 8.9 となり高めの值が示さ れたが, St.7ではその值は一旦低下し, St.5 から St.4 で 再び值が上昇した. St.3 では, 再度 pH の低下が見られ るが，ここには琵琶湖南湖からトンネルにより直結され た第 2 疏水が流れ込んでおり，その影響により $\mathrm{pH}$ が低 

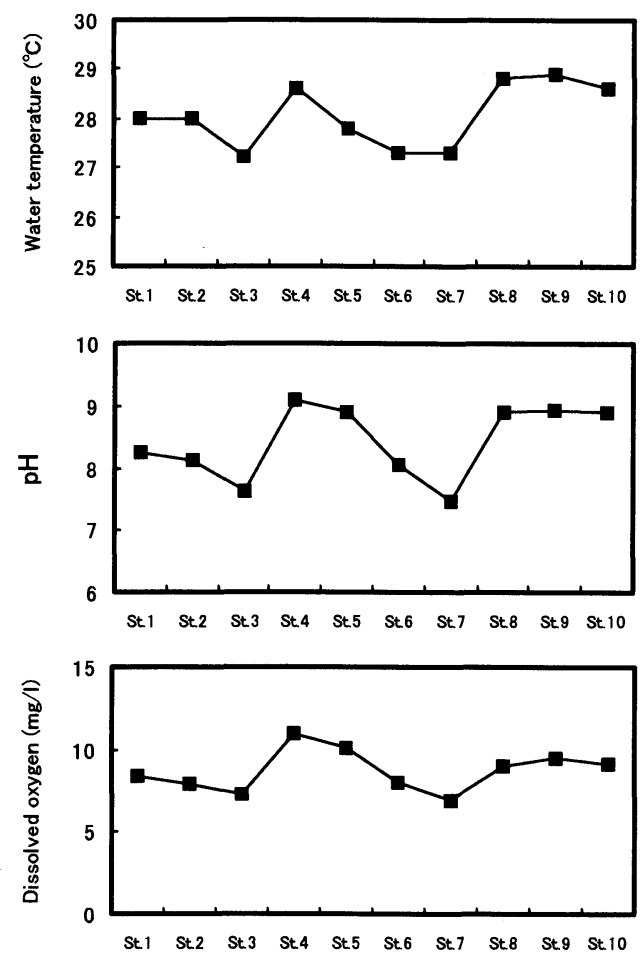

図-3 水温・ $\mathrm{pH} \cdot$ 溶存酸素の変化
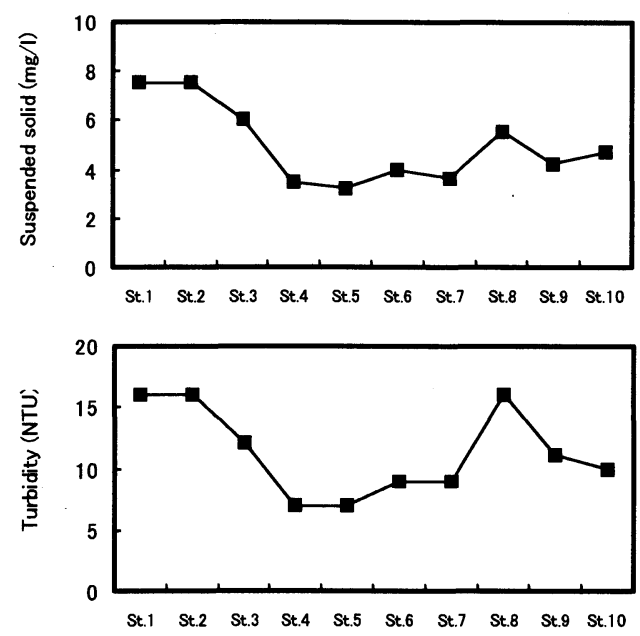

図-4 SS濃度および濁度の変化

下したものと考えられる. 溶存酸素濃度は，7～11mg/ の間で值は変化し,pH の変化と似たような傾向が示され た.

図-4に SS(Suspended Solid)濃度および濁度(Turbidity) の変化を示す. SS 濃度は 3.2 7.5mg/ の間で，濁度は

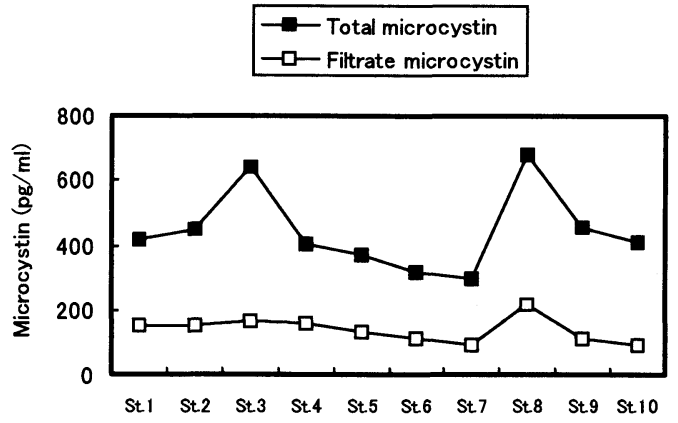

図-5 琵琶湖疏水におけるミクロシスチン濃度の変化

7〜16NTU (Nephelometric Turbidity Unit) の間で值は変 化した. SS 濃度は，St.8 で值の上昇が見られ $5.5 \mathrm{mg} /$ と いう值になったが, St.7 より下流側では SS 濃度は若干低 下した. St.3 から St.1 にかけて SS 濃度は再び上昇し, 6.0 〜 7.5mgl という值になった. 濁度についても SS 濃度の 変化と同じような傾向が示され, St.8 でその值は上昇し 16NTU という值になったが, St.7 より下流側では濁度は 低下した. St.3 から St.1 にかけてその值は再度上昇し, 12〜16NTU という值になった.

\section{（2）琵琶湖疏水におけるミクロシスチンの挙動}

ELISA法を用いて琵琶湖疏水から採取したサンプルを 分析した結果, 疏水の水からアオコに含有されている毒 素ミクロシスチンが検出された。琵琶湖疏水におけるミ クロシスチン濃度の変化を図-5に示す. ミクロシスチン は, 琵琶湖疏水全域において検出されたが，その濃度は 場所により異なっており，流下に伴いその濃度が低下し ていくわけではなく，下流側においても濃度が上昇する 地点が見られた。

ミクロシスチン濃度は, 琵琶湖南湖から水を取水して いる琵琶湖疏水取水口部の St.10 から St.8 にかけて高く なる傾向が見られ, 特に St.8においてその濃度は高くな り，680pg/ml にまで上昇した. St.8 の下流部には，琵琶 湖疏水の水量を制御する水門があり, St.8 では水の停滞 域がある. そのため, 浮遊性のラン藻類がその水域に留 まり，ミクロシスチン濃度も高い值を示したものと考え られる. St.8 より下流側の St.7 から St.4 では, ミクロシ スチン濃度は一旦低下し 300 410pg/ml という值になっ たが, St.3 においてミクロシスチン濃度は再ひ高くなり， 640pg/ml となった. St 3 にも水の停滞域が存在しており, 他の地点に比ベアオコを形成するラン藻類が多く浮遊し ていることが観察された. そのため, St.3 において水中 のミクロシスチン濃度も高い值を示したものと思われる。 琵琶湖疏水の水は, 京都市の重要な水道水源として利用 
されているが, St.3 の蹴上には京都市浄水場の取水口が ある. St3 の京都市浄水場の取水口付近よりミクロシス チンが検出されたことから, 京都市の水道原水にアオコ に含有される毒素ミクロシスチンが混入する事が予想さ れる. そのため, 琵琶湖においてアオコの発生が見られ る夏期には, 琵琶湖疏水におけるミクロシスチンの挙動 に十分注意を払う必要がある.

Ueno ら ${ }^{12)}$ は, タイ,ドイツ, 日本等において採取した サンプルについて, ELISA 法を用いそのミクロシスチン 濃度を調べている.タイにおいては, 貯水池や養魚池か ら 10 個のサンプルを採取しており,そのうち 6 個のサン プルがミクロシスチン陽性で，その平均濃度は $161 \mathrm{pg} / \mathrm{ml}$ であったと述べている. また，ドイツでは，レクリエー ションに使われているいくつかの湖においてサンプルを 採取しており,10個のサンプルのうち4個が陽性であり， その平均濃度は $257 \mathrm{pg} / \mathrm{ml}$ であったと記述している. また， 日本においては, 霞ヶ浦, 相模湖, 津久井湖などから 24 個のサンプルを採取しており,そのうち 14 個が陽性であ ったとしている. その濃度は, 55 1,300,000 pg/ml と広 範囲であり，特に霞ヶ浦において $1,300,000 \mathrm{pg} / \mathrm{ml}$ と高い 濃度が示されたと述べている. 今回の調査では, 琵琶湖 疏水において 300〜 680pg/ml の範囲でミクロシスチンが 検出された.この值は, タイやドイツで採取されたサン プルの平均濃度よりは高い值となっているが，霞ヶ浦な ど高濃度にアオコのブルームが発生する湖と比較すると， 低い値となっている。

ミクロシスチンには，構成するアミノ酸の違い等によ り 50 種類以上のミクロシスチンタイプが存在しており， それぞれその瑇性も異なっているが，日本においてはミ クロシスチン LR, YR, RR と呼ばれる 3 種類のミクロ シスチンが主要な成分であると言われている. ELISA 法 による分析では，ミクロシスチンの全体量は把握できる が，それぞれのミクロシスチンタイプに関する情報を得 ることはできない. そこで琵琶湖疏水におけるミクロシ スチンタイプの割合を見るため, ミクロシスチン LR, YR, RRの3種類のミクロシスチンについて, 高速液体 クロマトグラフィー（HPLC）を用いて分析を行った. 分析には, 他の地点に比べ比較的高いミクロシスチン濃 度が示された St.3 のサンプルを用いた。

分析の結果, St3 におけるミクロシスチン LR, YR, RRの割合は, それぞれ 52.4\%, 10.7\%, 36.9\%であった. 今回の分析においては，ミクロシスチン LR の割合が最 も多く, 52.4\%とミクロシスチンの半分以上を占めてい た. それに次いで多かったのはミクロシスチン RR で 36.9\%となり，ミクロシスチン YR の割合は他のミクロ シスチンタイプに比べて少ない傾向にあった. 日本の湖 沼におけるミクロシスチンの観測を見てみると，諏訪湖 においては ${ }^{13)}$,ミクロシスチン LR とミクロシスチン RR
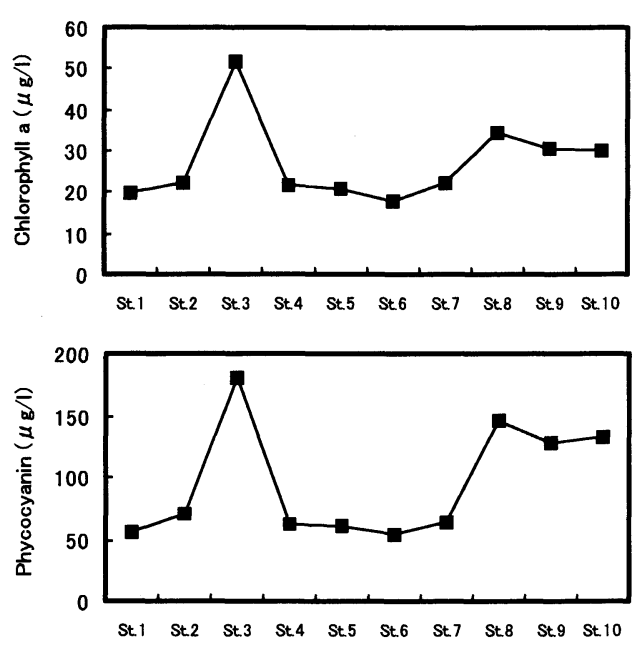

図-6 クロロフィルaおよびフィコシアニン濃度の変化

が主な成分で全ミクロシスチンの 90\%以上を占めてお り，ミクロシスチン YRは量的に少ないという結果が得

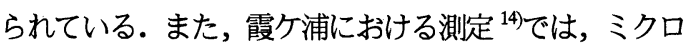
シスチン RRが最も多く全ミクロシスチンの約 $50 \%$ し くはそれ以上を占め，ミクロシスチン LR がそれに続く という結果が得られており, 諏訪湖の場合と同様, ミク ロシスチン YR の割合は少ないという結果が得られてい る. 今回の琵琶湖疏水サンプルに関する分析では，ミク ロシスチン LR が最も多く，全ミクロシスチンの $50 \%$ 以 上を占めており，ミクロシスチン RR の割合がそれに続 くという結果が得られた. ミクロシスチン LR はミクロ シスチン RRよりもその毒性が数倍強く ${ }^{15)-17)}, \mathrm{LD}_{50}$ 值は 60 100 $\mu \mathrm{g} / \mathrm{kg}$ でコレラ毒素の $2.5 \sim 4$ 倍の強さを持って おり ${ }^{1)}$, より注意が必要であると考えられる.

\section{（3）クロロフィルaおよびフィコシアニン濃度の変化と ミクロシスチンとの関連}

琵琶湖疏水におけるクロロフィルa濃度およびフィコ シアニン濃度の変化を図-6に示す. クロロフィルa濃度 は, 琵琶湖疏水取水口部の St.10 および St.9 では $30 \mu \mathrm{g} /$ という值になったが, St.8 ではその值は若干上昇し, 34 $\mu \mathrm{g} /$ という值になった. St.7 から下流側ではその值は低

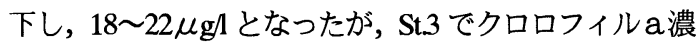
度は再び上昇し, $51 \mu \mathrm{g} /$ にな゙上昇した. 前述したよう に, St.3 においてはアオコを形成するラン藻類が多く浮 遊していることが観察されており，そのためクロロフィ ル a濃度も高い值が示されたものと推察される.

フィコシアニン濃度の変化もクロロフィルa濃度の変 化と同じような傾向が示された.フィコシアニン濃度は， 
琵琶湖疏水取水口部の St.10 および St.9 では, 127〜133 $\mu \mathrm{g} /$ という值になったが, St.8ではその值は上昇し 146 $\mu \mathrm{g} /$ という值になった. St.7 から下流側では，その值は 低下し 54 64 $\mu \mathrm{g} /$ の間で変化したが, St.3 でフィコシア ニン濃度は再び上昇し, $180 \mu \mathrm{g} /$ に達した。

クロロフィルaとフィコシアニン濃度の変化の様子は, 同じような傾向が示され，クロロフィルa濃度が上昇し た場合には，同様にフィコシアニン濃度の上昇が見られ た. クロロフィルaおよびフィコシアニン濃度の相関関 係を図-7に示す. 相関係数は, $r=0.945$ となり, 両者の 間には，良い相関関係が見られた.

琵琶湖疏水におけるラン藻類の優占率について調べる ために，フィコシアニンとクロロフィルa濃度の比を計 算した. その結果を図-8 示す. フィコシアニンとクロロ フィル a濃度の比は, 2.8 4.5 の間で変化した. 浮遊性 のラン藻類が比較的多く見られた St.10 から St.8 におい てその值は 4.2 4.5, St.3については 3.5 となり, 他の地 点に比べ, その值が高くなる傾向が見られた. フィコシ アニンの含有量は, 藻類の株によって, またその成長段 階によって異なってくると言われており, フィコシアニ ンとクロロフィル $\mathrm{a}$ 濃度の比も変動するものと思われる. 茨戸湖における調査 ${ }^{18) 199}$ では, ラン藻類が増加しその優 占率が上昇した場合には，フィコシアニンとクロロフィ ル a 濃度の比も上昇し, その值は 2 以上の值となってい る. 今回の観測においては, フィコシアニンとクロロフ イルa濃度の比はすべての地点において 2.8 以上の值が 示され，ラン藻類の多く見られた地点においては 3.5 以 上の值となっており, ラン藻類の優占率が高くなってい ることが推察される.

ミクロシスチンとの関連に目を向けると, 琵琶湖疏水 におけるクロロフィルa，フィコシアニン濃度とミクロ シスチン濃度の変化には関連が見られ,クロロフィルa， フィコシアニン濃度が上昇する地点においては, 同様に ミクロシスチン濃度の上昇か観察された. クロロフィル aおよびフィコシアニン濃度とミクロシスチン濃度との 相関関係を図-9 および図-10に示す. 図-9 には，クロロ フィルaおよびフィコシアニン濃度と全ミクロシスチン 濃度との相関関係を，図-10 には全ミクロシスチン濃度 からろ液中のミクロシスチン濃度を引いた值である粒子 態ミクロシスチン濃度との相関関係をそれぞれ示してい る.これらより, クロロフィルaおよびフィコシアニン 濃度とミクロシスチン濃度との間には正の相関関係が見 られ，クロロフィルaおよびフィコシアニン濃度の上昇 とともに，ミクロシスチン濃度も上昇するという結果が 得られた. 特に, 図-10 に示すように, クロロフィルa およびフィコシアニン濃度と粒子態ミクロシスチン濃度 との間により高い相関関係が見られ，クロロフィルaお よびフィコシアニンについての相関係数は，それぞれ

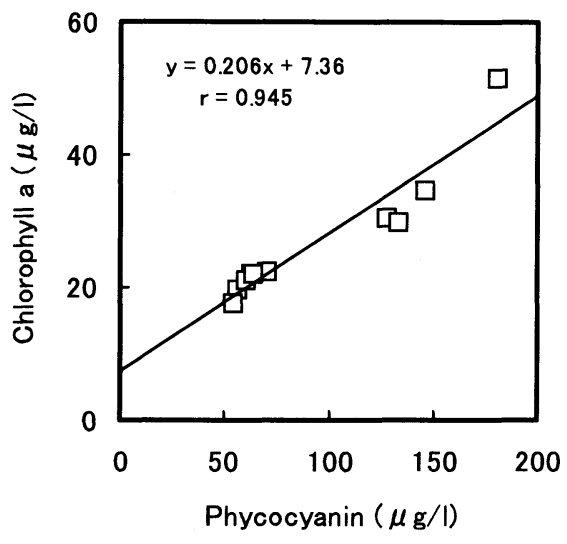

図-7 クロロフィルaとフィコシアニン濃度の相関

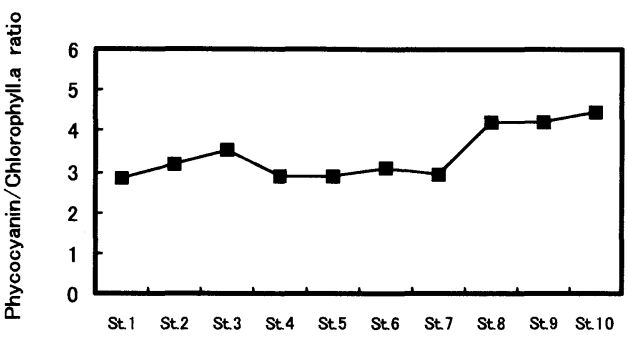

図-8 フィコシアニンとクロロフィルa濃度の比

0.898 および 0.920 という值になった.

水中のフィコシアニン濃度は, ラン藻類現存量の良い 指標となる. クロロフィルaやフィコシアニンは, 水中 に存在する植物プランクトンに含有される光合成色素で ある. 特にフィコシアニンは, ラン藻類や紅藻類などに 含まれているが, 淡水の湖沼等においては紅藻類は生育 していないため, アオコを形成するラン藻類現存量の良 い指標になると言われている ${ }^{10209}$. 今回の調査でフィコ シアニン濃度とミクロシスチン濃度との間に良い相関関 係が見られたことから,フィコシアニン現存量の測定は， 水中のミクロシスチン濃度を推察する上で, 重要な指標 になると考えられる.

\section{(4) 出現したプランクトンとミクロシスチンとの関連}

琵琶湖疏水で出現したプランクトンは，ラン藻類につ いては,Microcystis 属の Microcystis aeruginosa, Microcystis wesenbergii, Microcystis incerta, またAnabaena 属では, Anabaena spiroides, Anabaena affinis, Anabaena macrospora である. ラン藻類以外のものについては, 珪藻類の Melosira granulata, Fragilaria crotonensis, 緑藻類の Pediastrum biwae, Staurastrum dorsidenti ferum var. ornatum, 

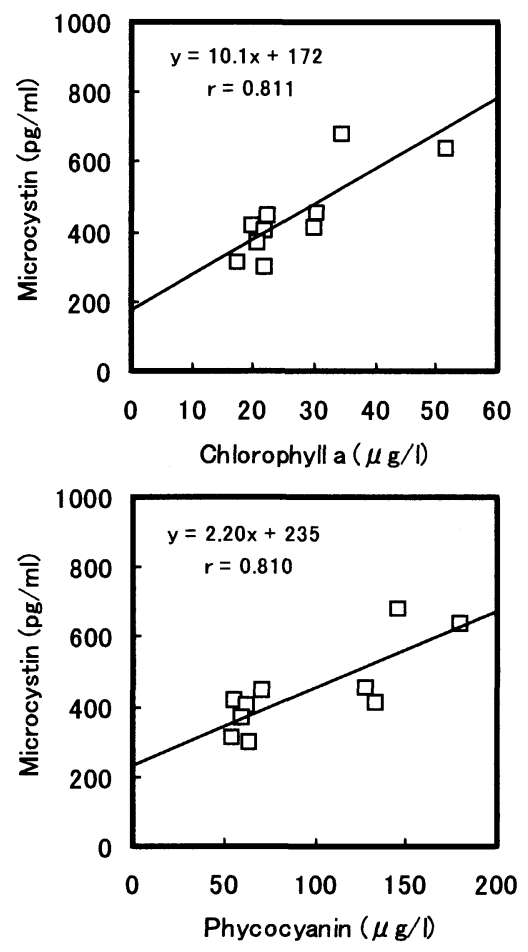

図-9 クロロフィルaおよびフィコシアニン濃度と 全ミクロシスチン濃度の相関
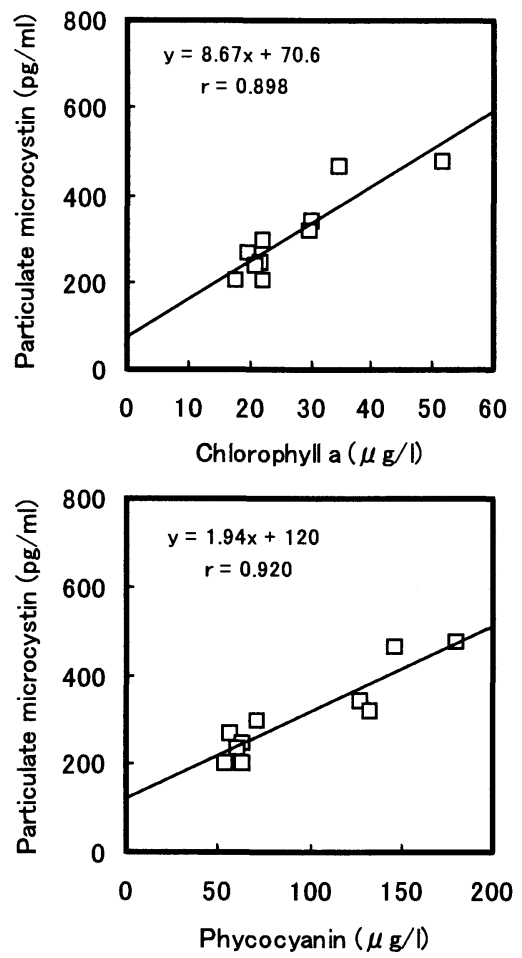

図-10 クロロフィルaおよびフィコシアニン濃度と 粒子態ミクロシスチン濃度の相関
渦鞭毛藻類の Ceratium hirundinella 等が出現した.

琵琶湖疏水で見られたアオコは, Microcystis ではなく Anabaena が優占的であった。琵琶湖疏水における Microcystis およびAnabaena 群体数の変化を図-11に示す. Anabaena のうち Anabaena spiroides が最も多く出現し, Anabaena affinis がそれに続いた. サンプリング地点の中 では, 特に St.3 の蹴上において Anabaena の群体数は多 くなり, Anabaena spiroides の群体数は 330 群体 $/ \mathrm{ml}$, Anabaena 属の合計では 391 群体/ml にまで上昇した. そ の他の地点については, St.8 において Anabaena 群体数 の増加が見られ, Anabaena の群体数は 140 群体/ml とな ったが, それ以外の地点においては, Anabaena 群体数の 大きな上昇は見られなかった. また, Anabaena affinis の 出現数は, Anabaena spiroides に比較して少なく, St.3に おいて Anabaena affinis の群体数が若干多くなり 56 群体 /ml となる他は,群体数の増加はあまり見られなかった. Anabaena macrospora については, その出現数はさらに少 なく, 1ml 中に数群体出現する程度であった.

Microcystis 属の群体数については, Anabaena 属に比較 すると少なかった. Microcystis 属のうち主として出現し たものは, Microcystis aeruginosa および Microcystis wesenbergii であり, Microcystis incerta の出現数はわずか
であった.サンプリング地点の中では, St.3 において Microcystis aeruginosa およびMicrocystis wesenbergii 群体 の出現数が他の地点に比較して多くなった. また, St.8 においても Microcystis 群体数の増加が見られた. St.3 お よびSt.8において Microcystis 属群体数の増加が見られた が，それに対応して水中ミクロシスチン濃度の上昇が見 られた. Microcystis 属群体数とミクロシスチン濃度の相 関関係を図-12 に示す. 図-12 には, Microcystis 属群体数 と全ミクロシスチン濃度の関係および Microcystis 属群体 数と粒子態ミクロシスチン濃度の関係がそれぞれ示され

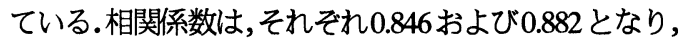
Microcystis 属群体数とミクロシスチン濃度の間には相関 が見られた。相関係数は, Microcystis 属群体数と粒子態 ミクロシスチン濃度の場合に, 全ミクロシスチン濃度の 場合よりも若干高い値となった.

St.3 においてはAnabaena spiroides の群体数について大 きな上昇が見られたが，ミクロシスチン濃度は St.8 の濃 度と同じレベルで $640 \mathrm{pg} / \mathrm{ml}$ となり, 大きな濃度の上昇は 見られなかった. ラン藻類に含有されている毒素ミクロ シスチンは Microcystis 属では Microcystis aeruginosa や Microcystis viridis, Microcystis ichthyoblabe に含有されてい ると言われている.Microcystis 属以外のものについては， 

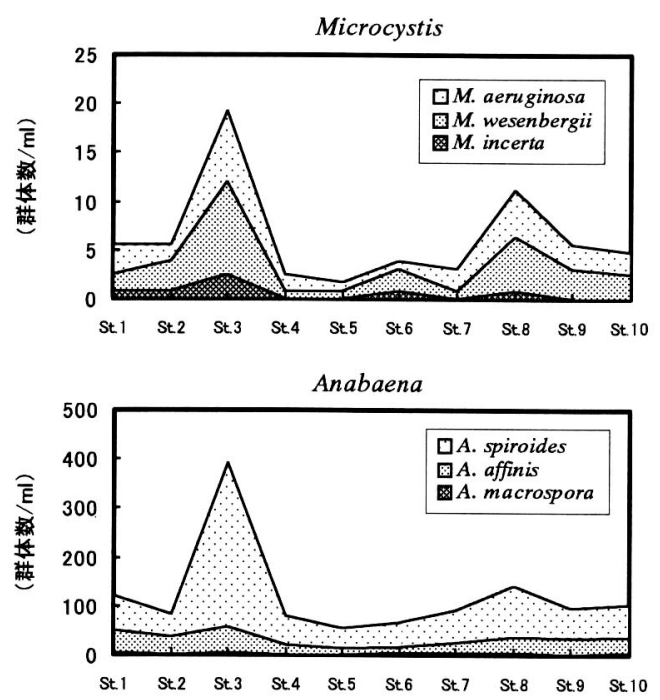

図-11 Microcystis およびAnabaena 群体数の変化

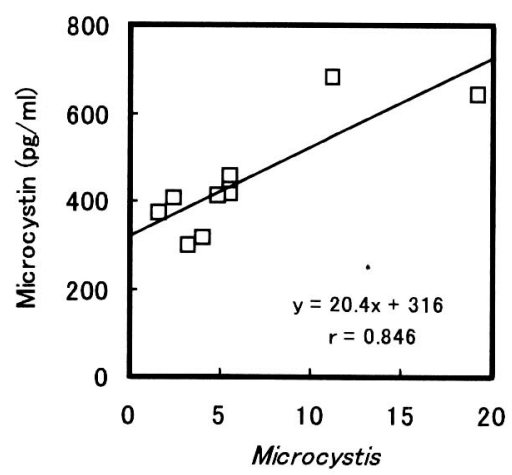

（群体数 $/ \mathrm{ml}$ )

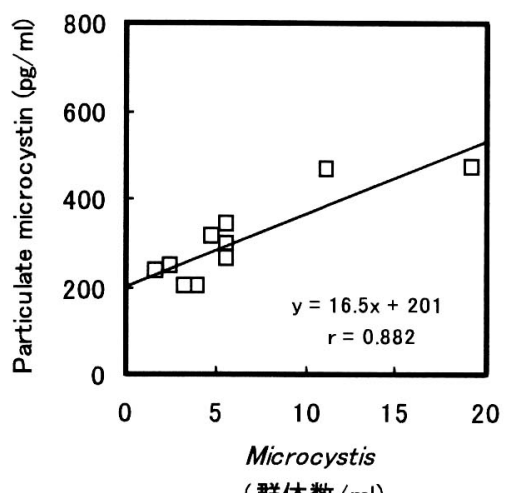

図-12 Microcystis 群体数と全ミクロシスチンおよび 粒子態ミクロシスチン濃度の相関
Anabaena 属の Anabaena flos-aquae や Oscillatoria 属の Oscillatoria agardhii からミクロシスチンの含有が報告さ

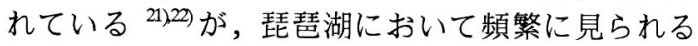

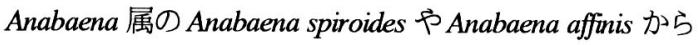
はミクロシスチンの含有は報告されていない. 今回発生 したアオコは, その多くが Anabaena 属のラン藻類によ って構成されており，そのため琵琶湖疏水におけるミク ロシスチンの濃度も最高で $680 \mathrm{pg} / \mathrm{ml}$ と比較的低い濃度 となった. 琵琶湖においては, Microcystis 属の Microcystis aeruginosa が優占したアオコの発生も見られることもあ り，その場合には水中のミクロシスチン濃度はさらに高 濃度になることが予想される.したがって, Microcystis 属が優占したアオコが発生した場合についても, 琵琶湖 疏水におけるラン藻類とミクロシスチンの挙動について, 今後調查・検討を行う必要があるものと考えられる.

\section{4. まとめ}

本研究では琵琶湖南湖でアオコの発生が観察された時 期に琵琶湖疏水においてサンプリングを行い，琵琶湖疏 水におけるラン藻類とその含有毒素ミクロシスチンの挙 動について検討を行った. その結果, 以下のようなこと が分かった.

1) 琵琶湖南湖においてアオコの発生が見られた時期に, 琵琶湖疏水において調査をおこなったところ,琵琶湖 疏水の水からラン藻類の生産する毒素ミクロシスチ ンが検出された。

2) ミクロシスチンは, 琵琶湖疏水の広い範囲から検出さ れたが,その濃度は300から 680pg/ml の間で変化し, 濃度が大きく上昇する地点が見られた。

3) 琵琶湖疏水において, クロロフィルa濃度は 17〜 51 $\mu \mathrm{g} /$ の間で, フィコシアニン濃度は 54 180 $\mu \mathrm{gl}$ の 間で変化した. また, クロロフィルaおよびフィコシ アニン濃度の間には，相関関係が見られた。

4) 水中のミクロシスチン濃度は, クロロフィルaおよび フィコシアニン濃度と相関関係が認められ,クロロフ イルaおよびフィコシアニン濃度が上昇した場合に は,ミクロシスチン濃度も上昇する傾向が認められた。

5) 琵琶湖疏水において, ラン藻類群体の出現数は場所に より変化が見られ, 群体の出現数が大きく増加する地 点が見られた. また, Microcystis 属群体の出現数とミ クロシスチン濃度の間には, 相関関係が見られた.

6) ミクロシスチンが琵琶湖疏水の水に混入しているこ とが観察された. 琵琶湖疏水の水は, 京都市の重要な 水道水源として利用されており,アオコ発生時期には, 琵琶湖疏水におけるミクロシスチンの挙動について 十分注意を払う必要があるものと考えられた。 


\section{参考文献}

1）渡辺真利代, 原田健一，藤木博太 : アオコ・その出現と毒 素, 東京大学出版, pp.55-73, 1994.

2) 原田健一 : 有毒ラン藻類をめぐる最近の研究動向, 衛生化 学, 45(3), pp.150-165, 1999.

3) Chorus, I. and Bartram, J. : Toxic Cyanobacteria in Water, A Guide to Their Public Health Consequences, Monitoring and Management, World Health Organization, pp.113-153, 1999.

4）彼谷邦光 : アオコの有毒物質の冓性について, 水環競学会 誌, 17(9), pp551-556, 1994

5) Yoshizawa, S., Matsushima, R, Watanabe, M., Harada, K, Ichihara, A., Carmichael, W.W. and Fujiki, H. : Inhibition of protein phosphatases by microcystin and nodularin associated with hepatotoxicity,J. Cancer Res. Clin. Oncol.,116, pp. 609-614, 1990.

๑) Nishiwaki-Matsushima, R., Ohta, T., Nishiwaki, S., Suganuma, M., Kohyama, K, Ishikawa, T, Carmichael, W.W. and Fujiki, H. : Liver tumor promotion by the cyanobacterial cyclic peptide toxin microcystin-LR, J. Cancer Res. Clin. Oncol., 118, pp.420-424, 1992.

7）山下尚之, 松田知成，松井三郎：ELISA法を用いたラン藻 毒ミクロシスチンの測定, 第5 回生物利用新技術研究シン ボジウム論文集, pp.179-183, 1998.

8) 山下尚之, 松田知成, 松井三郎 : 琵琶湖南湖におけるアオ コの発生とミクロシスチンの挙動,第 33 回日本水環境学会 年会講演集, p.215, 1999.

9) Nagata, S., Soutome, H., Tsutsumi, T., Hasegawa, A., Sekijima, M., Sugamata, M., Harada, K, Suganuma, M. and Ueno, Y. : Novel Monoclonal Antibodies Against Microcystin and Their Protective Activity for Hepatotoxicity,Natural Toxins, 3, pp.78-86, 1995.

10) Park, H.-D., Kim, B., Kim, E. and Okino, T. : Hepatotoxic Microcystins and Neurotoxic Anatoxina in Cyanobacterial Blooms from Korean Lakes, Environ. Toxicol. Water Qual., 13(3), pp.225-234, 1998.

11) Lorenzen, C. J. : A note on the estimation of chlorophyll a in freshwater algal communities, Lomnol. Oceanogr., 12, pp.340-346, 1967.

12) Ueno, Y., Nagata, S., Tsutsumi, T., Hasegawa, A., Yoshida, F, Suttajit, M., Mebs, D., Puetsch, M. and Vasconcelos, V. : Survey of microcystins in environmental water by a highly sensitive immunoassay based on monoclonal antibody,Natural Toxins, 4 , pp.271-276, 1996.

13) Park, H.-D., Watanabe, MF., Harad a, K., Suzuki, M, Hayashi, H. and Okino, T. : Seasonal variations of Microcystis species and toxic heptapeptide microcystins in Lake Suwa, Environ. Toxicol. Water Qual., 8, pp.425-435, 1993.
14) Watanabe, M.M., Kaya, K. and Takamura, N. : Fate of toxic cyclic heptapeptides, the microcystins, from bloom of Microcystis (cyanobacteria) in a hypertrophic lake,J. Phycol., 28, pp.761-767, 1992.

15) 彼谷邦光 : 藍藻毒ミクロシスチン (Microcystin) の化学と 䓯性, 環境化学, 2(3), pp.457-477, 1992.

10) 渡辺真利代, 原田健一：アオコとその毒素, 水処理技術, 33(7), pp.337-344, 1992.

17) 原田健一, 辻 清美, 近藤文雄 : アオコが生産する有毒ぺ プチドの化学と分析法, 水環境学会誌, 17(9), pp545-550, 1994.

18）日野修次, 高野敬志 : フィコシアニン濃度の変動からみた 湖沼におけるラン藻優占度の推定, 水処理技術, 34(4), pp.167-174, 1993.

19) 日野修次, 高野敬志 : 湖沼におけるラン藻優占度の推定, アオコの計量と発生状況・発生機構 アオコ検討会資料, 国立環境研究所, pp.15-23, 1995.

20) 大梘 晃, 大井武彦, 橋本信他, 相崎守弘, 高村典子 : 高 速液体クロマトグラフィーを用いたフィコシアニンの定 量法と霞ケ浦におけるラン藻類現存量変化に関する研究, アオコの計量と発生状況・発生機構 アオコ指標検討会資 料, 国立環境研究所, pp.7-14, 1995.

21) Harada, K., Ogawa, K, Kimura, Y., Murata, H., Suzuki, M., Thorn, PM., Evans, W.R., and Carmichael, W.W. : Microcystins from Anabaena flos-aquae NRC525-17, Chem. Res. Taxicol, 4, pp.535-540, 1991.

22) Meriluoto, J.A.O., Sandstrom, A., Eriksson, J.E., Remand, G., Graig, A.G. and Chattopadhyaya, J. : Structure and toxicity of a peptide hepatotoxin from the cyanobacterium Ocsillatoria agardhii, Toxicon, 24, pp.1021-1034, 1989.

(2000.10.6 受付) 


\section{BEHAVIOR OF CYANOBACTERIA AND ITS CONSTITUENT TOXIN MICROCYSTIN IN THE LAKE BIWA CANAL}

\section{Naoyuki YAMASHITA, Saburo MATSUI, Yoshihisa SHIMIZU andTomonari MATSUDA}

The Lake Biwa Canal is an artificial waterway from Lake Biwa to Kyoto City. In recent years, water bloom caused by cyanobacteria occurs in Lake Biwa and cyanobacterial toxin microcystin is detected from Lake Biwa water. Therefore samples were taken from the Lake Biwa Canal when water bloom occurred at Lake Biwa, behavior of cyanobacteria and its constituent toxin microcystin in the Lake Biwa Canal was investigated in this research. As a result, microcystin was detected from water of the Lake Biwa Canal and the microcystin concentration was mutually related to chlorophyll-a and phycocyanin concentration. Since microcystin was detected from water of the Lake Biwa Canal, it is considered that careful attention to microcystin behavior is needed in the Lake Biwa Canal when water bloom occurs at Lake Biwa. 